\title{
Studies on Minimally Processed Field Beans (Dolichos lablab) for Extending the Shelf-Life
}

\author{
Hima John ${ }^{1 *}$, Rajashekharappa ${ }^{2}$ and Venkarachalapathi ${ }^{2}$ \\ ${ }^{1}$ IARI, New Delhi (CIAE, Bhopal campus), India \\ ${ }^{2} U A S$, Bengaluru, Karnataka, India \\ *Corresponding author
}

\section{A B S T R A C T}

Field bean (Dolichos lablab) is an ancient legume crop widely grown throughout the world for its vegetable or pulse for human consumption or as animal forage or feed. Both whole

\section{Keywords}

Shelf life, Deskinned field bean, MAP

Article Info

Accepted:

04 May 2018

Available Online:

10 June 2018 bean and de-skinned bean can be used as a vegetable. The immature field bean is highly perishable and losses its quality immediately after the second or third day of de-skinning. The post-harvest loss in quality and commercial value is due to the intense respiratory activity and development of off flavour. Hence a study has been undertaken to increase the shelf-life of de-skinned beans by using various pre-treatments and passive MAP. The blanched and KMS treated samples along with the untreated samples as control were packed in 350 gauge LDPE and 250 gauge PP bags with $0 \%, 0.25 \%$ and $0.5 \%$ ventilations. And the study was conducted under low temperature storage $\left(4-5^{\circ} \mathrm{C}, 95 \% \mathrm{RH}\right)$ and the ambient storage conditions. The post-harvest behavior of the beans kept in all treatments was evaluated at an interval of 3 days. Observing the results of various analyses conducted, it was concluded that the KMS treated beans packed in $0 \%$ ventilation LDPE and PP packages showed a maximum shelf-life of 3 days under ambient storage condition and 12 days under refrigerated storage condition.

\section{Introduction}

Field bean (Dolichos lablab) is a dual-purpose legume. It is traditionally grown as a pulse crop for human consumption in south and south-east Asia and eastern Africa. They have a strong beany flavour and some people like to mix them with other beans or green vegetables. The immature seeds can be boiled and eaten like any shelly bean. In Asia, the mature seeds are made into tofu and fermented for tempe. They are also used as bean sprouts. In Karnataka, the field bean is made into curry (avarekaalusaaru), salad (avarekaaluusli), added to upma (avarekaaluuppittu) and as a flavouring to Akkirotti.

Sometimes the outer peel of the seed is taken out and the inner soft part is used for a variety of dishes. This form is called hitakubeleavarekaalu, which means pressed (hitaku) field bean, and a curry is made out of these de-skinned beans known as Hitikidaavarekasaaru. Legumes in their premature stage possess green appearance contain substantial amount of phytochemicals. 
During advanced maturity the contents of many of the phytochemicals with nutraceutical qualities decrease considerably due to biotransformation. Due to the presence of active enzymes and high moisture content, the legumes harvested at premature stage are susceptible to quick spoilage, and hence, they are not usually harvested at the early stage. However, a small proportion of some legumes which are harvested at premature stage are used as green vegetables. Most of the legumes are seasonal and they are not available to the consumer throughout the year. Hence, the possibility of processing the green legumes by retaining their nutrients and nutraceuticals has got high importance.

Minimal processing of raw fruit and vegetables has two purposes. First, it is important to keep the produce fresh, yet supply it in a convenient form without losing its nutritional quality. Second, the product should have a shelf life sufficient to make its distribution feasible to its intended consumers (Huxsoll and Bolin, 1989). The microbiological, sensory and nutritional shelf life of minimally processed vegetables or fruit should be at least 4-7days, but preferably even longer, up to 21 days depending on the market; the loss of ascorbic acid and carotenes is the main limiting factor of nutritional quality (Ahvenainen and Hurme, 1994). Demand for de-skinned fresh field bean is high in market and de-skinning is a tedious job. Very few studies have been reported on the fresh beans.

Hence it is of interest to study the effect of various types of processing methods to improve the shelf life and maintain the nutritive value of fresh de-skinned field beans. With this background information the present study has been taken up with the objective to study the suitability of various pretreatments and storage methods for the shelf life of fresh de-skinned field beans.

\section{Materials and Methods}

\section{Field bean sample collection}

Field beans (Dolichos lablab), which belong to the Hebbal Avere-1 were procured from the Integrated Farming System (IFS) plot, Department of Agroforestry, University of Agricultural Sciences, Bangalore. Pods were harvested at tender stage before it becomes fibrous. The beans were removed from pods and thoroughly washed. Beans were deskinned by manual squeezing after soaking it overnight.

\section{Physico-chemical characteristics estimation}

\section{Moisture content}

The moisture content of field bean was determined by gravimetric method. The stored samples were taken in petri dishes and the initial weight $\left(\mathrm{W}_{\text {initial }}\right)$ was measured. Samples were kept in a hot air oven maintained at a temperature of $70^{\circ} \mathrm{C}$ for 24 hours and the weight of the dried sample was taken ( $\mathrm{W}_{\text {final }}$ ). The moisture content was expressed as the percentage change in weight (Ranganna, 1995).

Moisture content $(\%)=\frac{\frac{W_{\text {initial }}-w_{\text {final }}}{w_{\text {final }}}}{w} \times 100$

\section{Total Soluble Solids (TSS)}

TSS was measured using a hand refractometer. Samples were crushed and made into juice. One or two drops of juice were placed on the hand refractometer for TSS measurement. It was expressed in degree Brix (Ranganna, 1995).

\section{Titratable acidity}

The field beans were crushed and filtered through a muslin cloth. About $10 \mathrm{~g}$ of fresh 
filtered homogenized field bean pulp was taken and made up to $100 \mathrm{ml}$ with distilled water. About $10 \mathrm{ml}$ of the prepared solution was titrated against $0.1 \mathrm{~N} \mathrm{NaOH}$ solution using $1 \%$ phenolphthalein indicator. Appearance of a light pink colour was the endpoint that quantifies the $\mathrm{NaOH}$ required to neutralize the juice. Then the titrable acidity was calculated and expressed as per cent anhydrous malic acid (Ranganna, 1995).

$\% \quad$ Total acid
$\frac{\text { Titre } \times \text { Normality of alkali } \times \text { Equivalent weight of acid } \times 100}{\text { Weight or volume of sample taken } \times 1000}$

\section{Firmness}

The firmness of field bean samples was evaluated by performing a puncture test on the beans using a Texture Analyser (TA-XT2 Stable with micro systems with a $100 \mathrm{~kg}$ load cell, equipped with needle probe) and taken the force value obtained during test during the storage period of field beans. The test settings of the texture analyser are given below:

Mode: Measure force in compression

Option: Return to start

Data acquisition rate: $400 \mathrm{pps}$

Pre-test speed: $1.5 \mathrm{~mm} / \mathrm{s}$

Test speed: $1 \mathrm{~mm} / \mathrm{s}$

Post-test speed: $10 \mathrm{~mm} / \mathrm{s}$

\section{Physiological loss in weight}

The PLW in field bean was calculated according to the method of Thakur et al., (2002). For determining the PLW, the products were weighed after imposing the treatment which served as the initial weight.

The loss in weight was recorded at regular interval until the product was spoiled, which served as the final weight. The PLW was determined by the following formula and expressed as percentage.
$\operatorname{PLW}(\%)=\frac{A-B}{A} \times 100$

A - Initial fruit weight (g)

B - Final fruit weight in the day of observation $(\mathrm{g})$

\section{Experimental details}

\section{Pre-treatments}

$\mathrm{T} 1$ : Blanching at $70^{\circ} \mathrm{C}$ for $2 \mathrm{~min}$.

T2: $2 \%$ potassium metabisulphite at $60^{\circ} \mathrm{C}$ for $2 \mathrm{~min}$.

T3: Control (untreated)

\section{Preparation of storage bags (LDPE and PP)}

Low Density Polyethylene (LDPE) of 345 gauge $(86.25 \mu \mathrm{m})$ and Polypropylene $(\mathrm{PP})$ of 252 gauge $(63 \mu \mathrm{m})$ bags measuring $5^{\prime \prime} \times 6^{\prime \prime}$ were used. Three levels of ventilations i.e. no ventilation, 0.25 per cent ventilation $(8$ holes or 4 punches) and 0.5 percent ventilation (16 holes or 8 punches) of $4 \mathrm{~mm}$ diameter each were made on both the sides of the bags for both LDPE and PP.

\section{Type of package with ventilation percentage}

$\mathrm{V}_{1}: 0.25$ per cent ventilation

$\mathrm{V}_{2}: 0.5$ per cent ventilation

$\mathrm{V}_{3}$ : no ventilation

\section{Packaging}

P1: LDPE @ 0.25 percent ventilation

P2: LDPE @ 0.5 percent ventilation

P3: LDPE@ 0.00 percent ventilation

P4: PP@ 0.25 percent ventilation

P5:PP@0.5 percent ventilation

P6: PP @ 0.00 percent ventilation 
Minimally processed de-skinned beans were then packaged in $100 \mathrm{~g}$ lots in packages and sealed with a sealing machine. The bagged minimal processed product was stored at ambient and refrigerated environments. Each treatment was replicated three times.

Thickness of LDPE bags: 345 gauge (86.25 $\mu \mathrm{m})$

Thickness of PP bags: 252 gauge $(63 \mu \mathrm{m})$

Size of bag: $5^{\prime \prime} \times 6^{\prime \prime}$

Storage conditions: 1) Ambient temperature;

2) Refrigerated condition $\left(4-5^{\circ} \mathrm{C}\right)$

Total No. of replications: 3

Design: Mixed factorial CRD

\section{Shelf-life of minimally processed field beans}

The packed minimally processed de-skinned beans kept at both ambient and refrigerated environment were observed and shelf-life was determined by looking into a number of physico-chemical parameters expressed in days.

\section{Gas composition determination}

One of the important parameters affecting the shelf life of the packed product is the gas composition inside the package. The gas composition inside the package was determined using $\mathrm{O}_{2} / \mathrm{CO}_{2}$ head space gas analyser (Check Mate2).

\section{Results and Discussion}

Physico-chemical characteristics of field beans

\section{Moisture content}

The initial moisture content of de-skinned bean was 62.6 per cent (dry basis). Moisture content of fresh untreated field bean samples was higher compared with the blanched and KMS pre-treated samples. In general, the field beans showed a decreasing trend in moisture content with storage irrespective of the pretreatments and the storage condition. In the ambient storage condition, the rate of reduction of moisture content was higher than that of the refrigerated storage condition. The reduction in moisture content with storage period is due to the exposure of internal tissues and the lack of skin or cuticle. This result is on par with the findings of Ayala et al., 2008.

The higher rate of water evaporation from minimally processed fruits and vegetables also causes a reduction in moisture content (Barry and O'Beirne, 1998). Because of the high RH inside the storage environment and packages, dehydration is not a problem for minimally processed fruits and vegetables (Siddiqui et al., 2011).

\section{Total soluble solids (TSS)}

In general, de-skinned beans showed an increasing trend in TSS with storage irrespective of the treatments. This may be due to the increased respiration rate and the transit of product towards ripening. The similar result was found by Chinchu and Hima (2013). Maximum TSS value $\left(22.86^{\circ} \mathrm{Brix}\right)$ was observed in blanched beans packed in LDPE bags with 0.5 Per cent ventilation.

Pre-treatments have a significant effect on the TSS content of both de-skinned field beans.

Among the various packaging conditions, the beans packed in $0 \%$ ventilation packages shows the least values for TSS after a storage period of 12 days. This may be attributed to retarded respiration due to the effect of passive MAP. This is in line with the findings of Mota et al., (2003). 


\section{Titratable acidity}

A gradual decrease in titratable acidity was shown by de-skinned bean during the storage time irrespective of the pre-treatments. This could be account for the degree of ripening of the fruits (Nunes et al., 2011). There was significant variation in titratable acidity with different pre-treatments applied with the storage period.

\section{Firmness}

Under ambient storage condition the firmness values showed a gradual decrease with the storage period. Under refrigerant storage conditions there observed an initial increase and then a gradual decrease in firmness values (Fig. 1). The trend in the variation of ' $A$ ' value (toughness) also is the same.

Initial firmness values of pre-treated deskinned beans are higher than that of the untreated beans. The pre-treatments were having a significant effect on the firmness values of de-skinned beans with the storage period. The rate of reduction of firmness is higher in the ambient storage condition as compared with the low temperature storage condition.

The initial increase in the firmness values under refrigerated storage condition may be due to the hardening caused by the effect of low temperature storage. The decline in firmness after this hike may account to the increased ripening of the products. This result is in line with the findings of Chinchu and Hima (2013).

The minimum firmness values may be due to the increased metabolic activities. This result corresponds with the results of Fahad et al., 2012. The higher firmness values for the pretreated de-skinned beans may due to the tempering effect caused by the heat treatment.

\section{Physiological loss in weight}

Apart from the control samples, maximum PLW was observed in the KMS treated deskinned bean packed in PP bags with $0.5 \%$ ventilation $(4.67 \%)$ at the end of $12^{\text {th }}$ day of storage. The minimum PLW was observed in blanched de-skinned bean packed in 0\% PP bags $(0.74 \%)$. The rate of increase of PLW with the storage period is higher for untreated samples than the pre-treated de-skinned beans. The expected reason for increased weight loss might be due to the increased water vapour transmission. The increased PLW causes a reduction in the consumer acceptability (Wills et al., 1998). The field beans stored under ambient storage condition exhibited higher percentage of PLW than the beans stored under refrigerated storage condition. These results correspond with the findings of Shellhammer and Krochta (1997).

\section{Gas kinetics under MAP}

Among the packages blanched de-skinned beans packed in LDPE bags has the minimum percentage of $\mathrm{CO}_{2}(9.7 \%)$ when compared to the other treatments. The untreated de-skinned bean showed the highest percentage of $\mathrm{CO}_{2}$ after a storage period 12 days $(25.9 \%)$. With the storage time, the magnitude of the $\mathrm{CO}_{2}$ increase and $\mathrm{O}_{2}$ decrease inside the package. This $\mathrm{CO}_{2}$ enrichment and $\mathrm{O}_{2}$ depletion is due to the respiration of products inside the enclosed packages (Sudheer and Indira, 2007). The $\mathrm{CO}_{2}$ content was more in the packets with untreated de-skinned beans. This may be due to the higher metabolic activity of the beans. This result corresponds with that of Singh et al., (1998).

\section{Shelf-life of minimally processed field beans}

The pre-treated samples packed in LDPE and PP with no ventilation ( $0 \%$ ventilation) performed best during investigation. 
Fig.1 Variation in textural properties of various pretreated de-skinned field beans during storage at refrigerated conditions
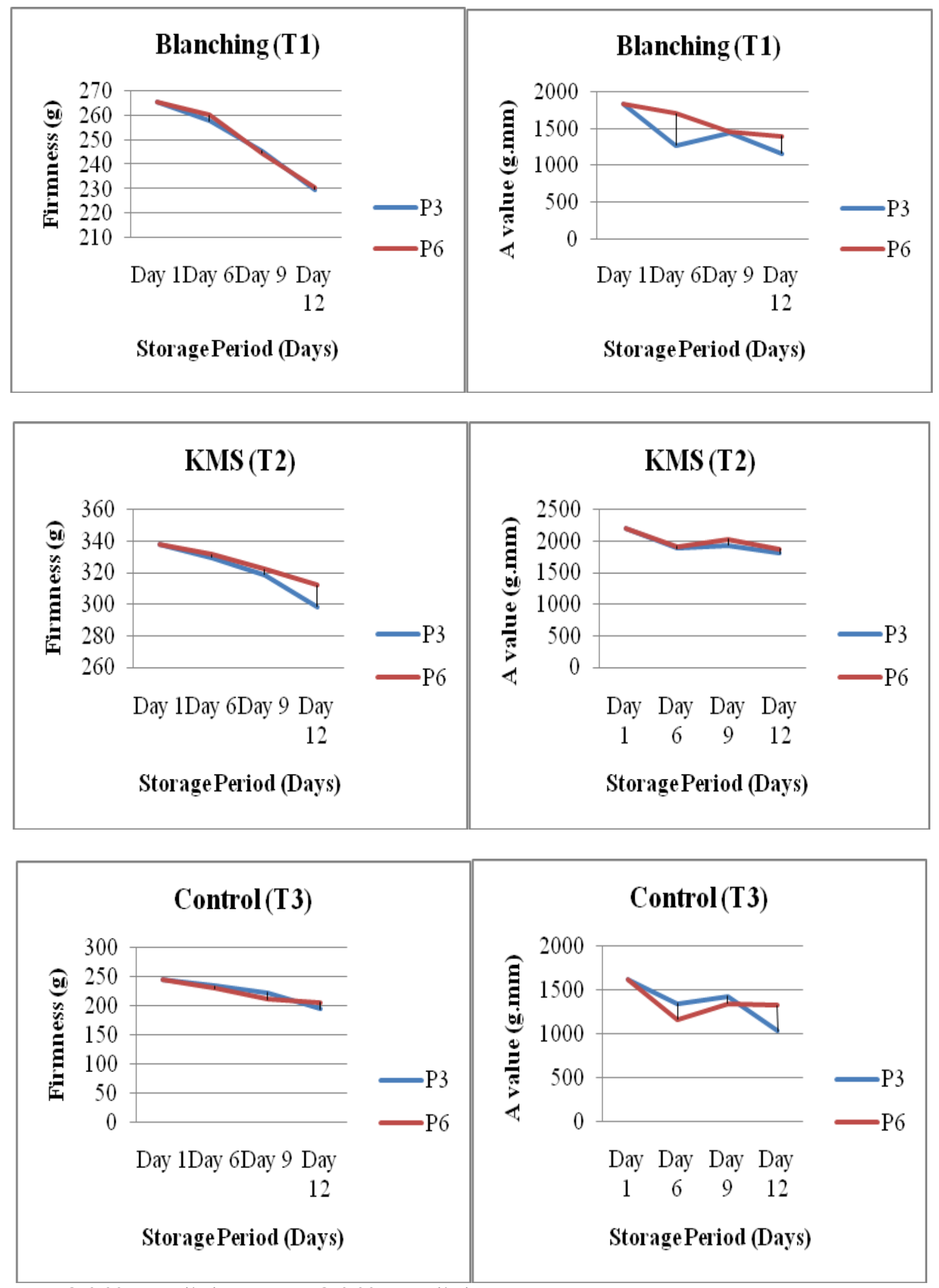

P3: LDPE @ 0.00\% ventilation; P6: PP @ 0.00\% ventilation 
Plate. a, b Path diagram of important qualitative traits influencing the shelf-life of minimally processed de-skinned field beans packed in LDPE and PP bags

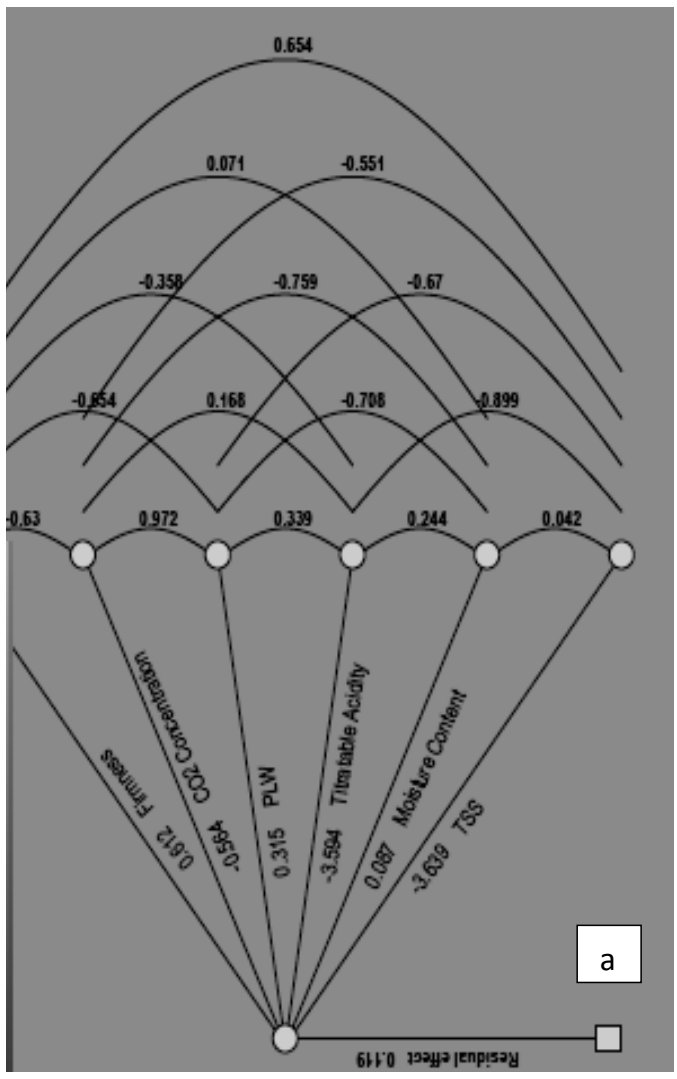

Based on significant difference in overall quality scored the shelf-life of minimally processed field beans was higher (12 days) in refrigerated condition compared to that of ambient storage (3 days).

\section{Path coefficient analysis}

In the present study path coefficient analysis was done for shelf-life as dependent variable and other qualitative traits (firmness, $\mathrm{CO}_{2}$ concentration, PLW, titratable acidity, moisture content and TSS) as independent variables and are illustrated in plate a, b. In the case of de-skinned field bean packed in LDPE bags, firmness had the highest positive direct effect (0.6116) on shelf-life followed by PLW (0.3152) and moisture content (0.0869). The TSS $(-3.6386)$ had the highest negative direct effect on shelf-life of de-

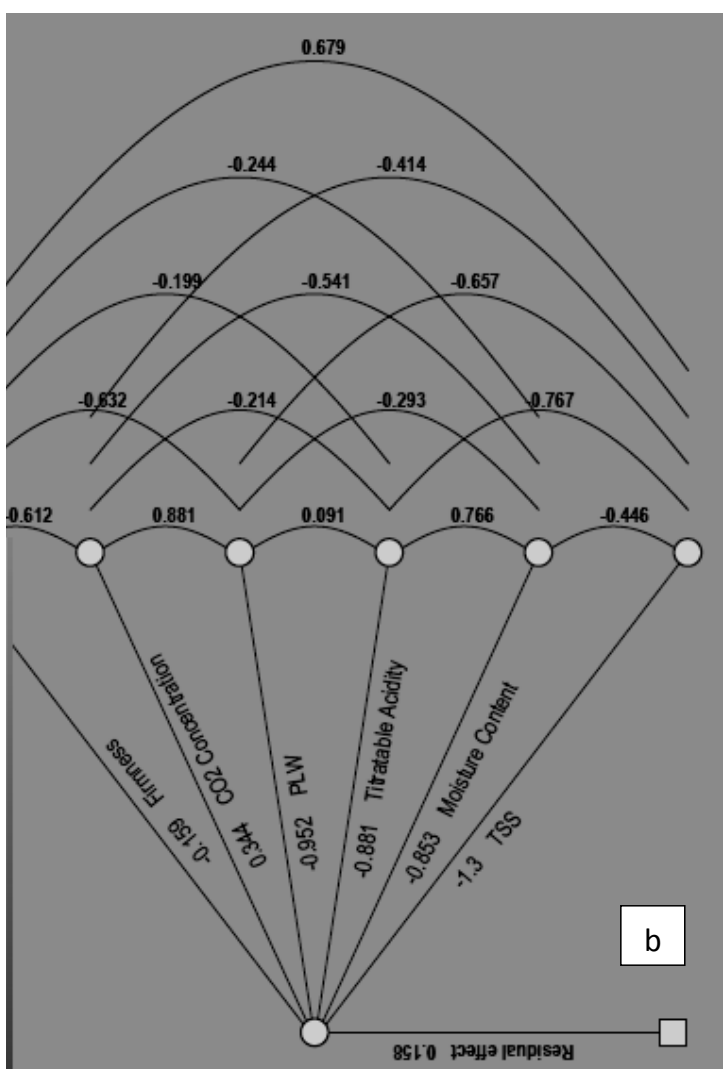

skinned beans followed by titratable acidity (3.5940) and $\mathrm{CO}_{2}$ concentration (-0.5643). The $\mathrm{R}^{2}$ value was 0.9860 and $98.60 \%$ of the variability in shelf-life can be expressed by these independent variables.

$\mathrm{CO}_{2}$ concentration $(0.3437)$ had the positive direct effect on the shelf-life of de-skinned field bean packed in PP bags. The rest of the independent variables were having negative indirect effects on the shelf-life. The highest negative direct effect was shown by TSS (1.2999) followed by PLW (-0.9524), titratable acidity (-0.8806), moisture content (-0.8533).

The lowest negative direct effect on shelf-life was shown by firmness $(-0.1588)$. The $\mathrm{R}^{2}$ value was 0.9750 and $97.50 \%$ of the variability in shelf-life can be expressed by these independent variables. 


\section{Economic analysis}

The cost incurred for packaging $1 \mathrm{~kg}$ of minimally processed de-skinned bean in LDPE bags and PP bags under ambient storage condition was Rs. 110.24/respectively. Under ambient storage condition the cost for packaging $1 \mathrm{~kg}$ of minimally processed de-skinned bean was Rs. 167.14/and Rs. 161.35/- respectively. However under refrigerated storage conditions, for de-skinned beans, the cost for packaging in LDPE and PP bags was Rs. 189.08/- and Rs. 183.3/respectively.

Benefit-cost ratio for minimally processed field bean under ambient condition:

Benefit cost ratio for minimally processed deskinned field beans packed in LDPE $=1.19: 1$

Benefit cost ratio for minimally processed deskinned field beans packed in $\mathrm{PP}=1.24: 1$

Benefit-cost ratio for minimally processed field bean under refrigerated condition:

Benefit cost ratio for minimally processed deskinned field beans packed in LDPE $=1.21: 1$

Benefit cost ratio for minimally processed deskinned field beans packed in $\mathrm{PP}=1.25: 1$

Field bean or Dolichos bean is an ancient legume crop widely grown throughout the world for its use as a vegetable or pulse for human consumption or as animal forage or feed. It is one of the lesser-known legumes of arid and semi-arid land. Immature de-skinned field bean is commonly used as a vegetable as well a supplement in breakfast items especially in Karnataka and Andra Pradesh.

De-skinning is a tedious job and the shelf life of de-skinned bean is maximum one day without any pre-treatments.
The minimally processed and de-skinned bean packed in LDPE and PP bags showed a maximum shelf-life of 3 days under ambient storage condition and 12 days under refrigerated storage condition. The pre-treated samples exhibited better quality parameters than the untreated samples. Observing the results of various analyses conducted, it is concluded that the pre-treated beans packed in 0 per cent ventilation LDPE and PP packages stored under refrigerated storage condition proved to be the best in terms of physical, biochemical and sensory characteristics.

\section{References}

Ahvenainen, R and Hurme, E., 1994, Minimal processing of vegetables, in minimal processing of foods.V77 Symposium Series No. 142.Technical Research Centre of Finland (VTT), Espoo, Finland, p:17-35.

Ayala-Zavala, J. F., Del-Toro-Sánchez, L., Alvarez-Parrilla, E. and GonzálezAguilar, G. A., 2008, High relative humidity in-package of fresh-cut fruits and vegetables: Advantage or disadvantage considering microbiological problems and antimicrobial delivering systems. $J$. Food Sci., 73: 41-47.

Barry-Ryan, C. and O'beirne, D., 1998, Quality and shelf-life of fresh-cut carrot slices as affected by slicing method. $J$. Food Sci., 63: 851-856.

Chinchu, M. and Hima, J. 2013, Effect of edible wax coating and modified atmospheric packaging on shelf-life of slicing cucumber (Cucumis sativus), B. Tech thesis (Unpub.), Kerala Agricultural University.

Fahad, A. J., Kashif, G. and Elfadil, E. B., 2012, Effect of gum arabic edible coating on weight loss, firmness and sensory characteristics of cucumber 
(Cucumis sativus L.) fruit during storage. Pak. J. Bot. 44(4): 1439 - 1444.

Huxsoll, C. C. and Bolin, H. R., 1989, Processing and distribution alternatives for minimally processed fruits and vegetables. Food Technol., 43: 124-1 28.

Mota, W. S. S., Salomao, L. C. C., Cecon, P. R. and Fernando, L. F., 2003, Waxes and plastic film in relation to the shelf life of yellow passion fruit. Scientia Agricola. 60: 51 - 57.

Nunes, M. C. N., Emond, J. P., Sharon, D. and Yavuz, Y., 2011, Distribution center and retail conditions affect the sensory and compositional quality of bulk and packaged slicing cucumbers. Postharvest. Biol. Technol., 59: 280 288.

Ranganna, S., 1995, Hand book of analysis of quality control for fruit and vegetable products (1st Ed.). Tata McGraw hill publishing Co, Ltd., New Delhi.

Shellhammer, T. H. and Krochta, J. M., 1997, Whey protein emulsion film performance: Effect of lipid type and amount. J. Fd. Sci., 32: 390-394.
SiddiquI, M. W., Chakraborty, I., AyalaZavala, J. F. and Dhua, R. S., 2011, Advances in minimal processing of fruits and vegetables: a review. $J$. of Scientific \& Industrial Research, 70: 823-834.

Singh, M., Panesar, P. S. and Marwaha, S. S., 1998, Studies on the suitability of Kinnowfrutis for the production of wine. J. Fd. Sci. Technol., 35(5): 455457.

Sudheer, K. P. and Indhira, V., 2007, Postharvest Technology of Hoticultural Crops. New India Publishing house, Pitampura, New Delhi, p: 291.

Thakur, K. S, Kaushal, B. B. L. and Sharma, R. M., 2002, Effect of different postharvest treatments and storage conditions on the fruit quality of Kinnow. J. Fd. Sci. 39(6): 609 - 618.

Wills, R., Mcglasson, B., Graham, D. and Joyce, D., 1998, An introduction to the physiology and handling of fruit, vegetables and ornamentals. ( $4^{\text {th }} \mathrm{Ed}$.), UNSW press. Sydney. Pp. 264.

\section{How to cite this article:}

Hima John, Rajashekharappa and Venkarachalapathi. 2018. Studies on Minimally Processed Field Beans (Dolichos lablab) for Extending the Shelf-Life. Int.J.Curr.Microbiol.App.Sci. 7(06): 642-650. doi: https://doi.org/10.20546/ijcmas.2018.706.074 